\title{
Pengaruh Strategi Pembelajaran dan Gaya Kognitif Spasial Terhadap Hasil Belajar Ikatan Kimia SMA
}

\author{
Intan Rosari ${ }^{1}$ \\ 1 Program Studi Magister Penelitian dan Evaluasi Pendidikan, Universitas Muhammadiyah Prof. Dr. \\ Hamka, Jakarta, Indonesia \\ Coressponding Author. E-mail: \\ 1 intan.rosari.ir@gmail.com
}

Received: 5 Juli 2019

Accepted: 28 Juli 2019

Online Published: 30 Juli 2019

\begin{abstract}
Abstrak
Penelitian ini bertujuan untuk menentukan pengaruh strategi pengorganisasian isi pembelajaran dan gaya kognitif spasial terhadap hasil belajar siswa pada materi Ikatan Kimia. Penelitian ini dilaksanakan di SMA Global Islamic School Jakarta dan SMA PB Sudirman Jakarta. Sampel sebanyak 56 siswa untuk menentukan gaya kognitif spasial kemudian dibagi menjadi gaya kognitif spasial tinggi dan gaya kognitif spasial rendah. Dalam uji persayaratan analisis meliputi Uji Normalitas dengan Uji Liliefors dan Homogenitas dengan Uji Bartlett;untuk uji hipotesis digunakan analisis varians dua jalur (2x2). Hasil belajar siswa lebih meningkat menggunakan Strategi Pengorganisasian Pembelajaran Model Component Display Theory Merrill dibandingkan dengan Strategi Pengorganisasian Pembelajaran Model Pembentukan Konsep; (1) gaya kognitif spasial merupakan salah satu karakteristik siswa yang berpengaruh terhadap tingkat pencapaian hasil belajar Ikatan Kimia; (2)Siswa yang memiliki Gaya Kognitif Spasial Tinggi memberikan hasil belajar Ikatan Kimia yang lebih baik dibandingkan dengan siswa yang memiliki Gaya Kognitif Spasial Rendah; (3)terdapat interaksi antara strategi pembelajaran dengan gaya kognitif spasial siswa. Bagi siswa yang memiliki Gaya Kognitif Spasial Rendah, penerapan Strategi Pembelajaran CDT Merrill lebih efektif dalam meningkatkan hasil belajar Ikatan Kimia, dibandingkan dengan Strategi Pembelajaran PK Taba; (4) bagi siswa yang memiliki Gaya Kognitif Spasial Tinggi, kedua strategi pembelajaran dapat diterapkan, karena memberikan hasil belajar yang sama baiknya.
\end{abstract}

Kata Kunci: Inkuiri Terbimbing; Hasil Belajar; Metode Pembelajaran

\begin{abstract}
This study aims to determine the effect of the strategy of organizing learning content and spatial cognitive style on student learning outcomes in the Chemical Bonding material. This research was conducted at the Global Islamic School Jakarta High School and PB Sudirman High School Jakarta. A sample of 56 students to determine spatial cognitive style was then divided into high spatial cognitive style and low spatial cognitive style. In the analysis requirements test includes the Normality Test with Liliefors Test and Homogeneity with the Bartlett Test, for the hypothesis test used two-way variance analysis (2x2). Student learning outcomes are further improved using the Organizational Component Display Theory Merrill Model Organizational Learning Strategy compared to the Organizing Strategy for Concept Formation Learning Model; (1) spatial cognitive style is one of the characteristics of students that influences the level of achievement of Chemistry Bond learning outcomes; (2) Students who have High Spatial Cognitive Style give better Chemical Bond learning outcomes compared to students who have Low Spatial Cognitive Style; (3) there is an interaction between learning strategies and students' spatial cognitive styles. For students who have a Low Spatial Cognitive Style, the application of the Merrill CDT Learning Strategy is more effective in improving the learning outcomes of Chemical Bonds, compared to the PK Taba Learning Strategy; (4) for students who have a High Spatial Cognitive Style, both learning strategies can be applied, because they provide equally good learning outcomes.
\end{abstract}

Keywords : Guided Inquiry; Learning Outcomes; Learning Method

How to cite this article :

Rosari, I. (2019). Pengaruh strategi pembelajaran dan gaya kognitif spasial terhadap hasil belajar ikatan kimia sma. IJIS Edu : Indonesian Journal of Integrated Science Education, 1(2), 163-168.

doi:http://dx.doi.org/10.29300/ijisedu.v1i2.1966 


\section{PENDAHULUAN}

Salah satu faktor yang sangat strategis dan substansial dalam upaya peningkatan kualitas Sumber Daya Manusia (SDM) suatu bangsa adalah pendidikan. Pada saat ini pendidikan menjadi fenomena permasalahan yang sangat penting di Indonesia .Peningkatan kualitas pendidikan dilakukan secara bertahap dan berkesinambungan pada berbagai komponen pendidikan antara lain adalah menyempurnakan kurikulum. Pembaruan dalam bidang kurikulum yang telah dilakukan pemerintah adalah penyempurnaan kurikulum 2013.

Pembangunan sistem pendidikan tidak dapat mengingkari ataupun mengabaikan berbagai dampak dan kecendrungan sains (Chusnani, 2013). Fokus pendidikan terutama adalah menumbuhkan "budaya sains" melalui peningkatan upaya melek pikir. Sains dan teknologi persekolahan harus dapat mengkaji dan menterjemahkan pengalaman manusia tentang dunia fisik dengan cara teratur dan sistematis . Sains yang dimaksudkan disini adalah sains dalam arti luas, mencakup semua aspek pengetahuan yang dihasilkan oleh aplikasi metode ilmiah, bukan saja fakta dan konsep proses ilmiah, tetapi juga berbagai variasi aplikasi pengetahuan dan prosesnya seperti penguatan, pengelompokkan, perkiraan, serta penilaian dan interpretasi.

Ilmu kimia merupakan salah satu cabang dari Ilmu Pengetahuan Alam (IPA). Ilmu Pengetahuan Alam dikembangkan di sekolah dengan mengarahkan siswa untuk "mencari tahu" dan "berbuat" sehingga dapat membantu siswa untuk memperoleh pemahaman yang lebih mendalam tentang alam sekitar, dan pemahaman terhadap ilmu kimia termasuk di dalamnya

Permasalahan yang dihadapi siswa dalam keterbatasan memahami suatu konsep materi kimia dapat diatasi dengan adanya bahan ajar, yakni berupa modul pembelajaran kimia, yang berisi materi, metode, dan evaluasi yang dirancang secara sistematis, menarik untuk mencapai kompetensi yang ditetapkan, dan membantu siswa dalam mencapai tujuan instruksional. Penggunaan modul pembelajaran akan dapat mempermudah siswa dalam memahami mata pelajaran kimia.

Ditinjau dari sudut pandang teknologi pendidikan/pembelajaran dengan mengacu pada kerangka teori pembelajaran, masalah rendahnya kualitas pembelajaran dapat diklasifikasikan sebagai berikut : (a) masalah yang bersumber dari kondisi pembelajaran, meliputi karakteristik siswa dan karakteristik materi/konsep kimia; dan (b) masalah yang bersumber dari metode pembelajaran yang digunakan oleh guru
Masalah yang bersumber dari karakteristik siswa, ditandai dengan adanya kesulitan siswa sebagai akibat kerancuannya (konsepsi yang salah) dalam memahami konsep kimia dengan benar. Untuk mengatasi hal tersebut, maka diperlukan strategi pengorganisasian yang tepat untuk menyajikan informasi ilmu kimia kepada siswa.

Strategi pengorganisasian pembelajaran dapat dibedakan menjadi dua jenis yaitu strategi (1) makro dan (2) mikro. Strategi pengorganisasaian tingkat makro mengacu pada cara memilih, mengurutkan, mensintesis, dan merangkum dari sejumlah isi bidang studi yang berkaitan.

Salah satu strategi pengorganisasian pembelajaran mikro adalah Component Display Theory (CDT), yang merupakan strategi pemahaman dan pembentukan konsep. Ruang lingkup CDT terbatas pada ranah kognitif dan menjabarkan petunjuk rinci tentang pembelajaran, yang tidak dijumpai pada teori pembelajaran lain.

Strategi pengorganisasian pembelajaran mikro lain yang diprediksi dapat memudahkan siswa memahami konsep adalah model pembentukan konsep Hilda Taba, dengan pendekatan induktif. Model ini terdiri atas tiga tahapan pembelajaran, yaitu (1) pembentukan konsep; (2) interpretasi, dan (3) aplikasi prinsip.

\section{METODE PENELITIAN}

Penelitian ini bertujuan untuk mengetahui perbedaan pengaruh dari variabel-variabel bebas, yaitu strategi pengorganisasian isi pembelajaran dan gaya kognitif spasial terhadap hasil belajar siswa sebagai variabel terikat. Penelitian ini dilakukan di SMA Global Islamic School dan SMA PB Sudirman Jakarta dari bulan Mei 2015. Perlakuan penelitian dilaksanakan selama 2 bulan. Pertemuan pertama melaksanakan tes pendahuluan. Pertemuan kedua sampai dengan ke lima melaksanakan perlakuan. Pertemuan ke enam melaksanakan tes akhir. Pelaksanaan perlakuan disesuaikan dengan jadwal pelajaran yang ada di sekolah.

Populasi target adalah siswa kelas X IPA SMA Global Islamic School dan SMA PB Sudirman tahun ajaran 2014-2015 berjumlah 190 orang. Jumlah seluruh siswa kelas X IPA SMA Global Islamic School adalah 72 orang, tersebar pada tiga kelas, yaitu : (1) kelas X MIA1 = 24 siswa, (2) kelas X MIA $2=24$ siswa, dan (3) kelas X MIA $3=24$ siswa, sedangkan jumlah siswa kelas X IPA SMA PB Sudirman adalah 118 orang, tersebar pada empat kelas, yaitu : (1) kelas X MIA $1=30$ siswa, (2) kelas X MIA $2=30$ siswa, (3) kelas X MIA $3=$ 28 siswa, dan (4) kelas X MIA $4=30$ siswa. Siswasiswa pada kelas perlakuan ini, belum pernah 
menerima materi pelajaran tentang topik Bentuk Molekul Senyawa berdasarkan Teori Hibridisasi. Dengan demikian, pesan ajaran merupakan pengetahuan baru bagi seluruh anggota subyek penelitian.

Pengambilan sampel dilakukan secara acak (two stages random sampling) melalui prosedur berikut

a. Pertama dilakukan undian untuk menentukan dua kelas dari masing-masing kelas yang ada di tiap sekolah. Dua kelas yang dipilih di masingmasing sekolah harus memiliki kemampuan yang homogen. Dua kelas hasil undian pada masing-masing sekolah kemudian ditetapkan sebagai kelas perlakuan

b. Kedua, dilakukan undian lagi untuk menentukan kelompok kelas mana yang akan menggunakan strategi pembelajaran berdasarkan model CDT Merrill, dan kelompok kelas yang akan menggunakan strategi pembelajaran berdasarkan model PK Taba.

Karena seluruh siswa pada tiap kelompok kelas perlakuan belum pernah memperoleh atau menerima materi Ikatan Kimia, maka diasumsikan bahwa kedua kelompok subyek yang dipilih memiliki kemampuan yang sama. Asumsi tersebut diperkuat dengan hasil uji pendahuluan, di mana dengan menggunakan uji kesamaan dua rerata (uji t), terbukti bahwa kedua kelompok kelas yang menjadi subyek penelitian memiliki spesifikasi yang sama

Tes ini terdiri dari 60 soal dalam bentuk pilihan ganda. Setiap soal yang dijawab benar diberikan skor 1 (satu), dan jawaban yang salah atau tidak dijawab diberikan skor 0 (nol). Rentangan skor yang diperoleh pada tes ini adalah 0 sampai 60 .

Pengelompokan subyek penelitian didasarkan pada tinggi rendahnya skor yang diperoleh dalam menjawab butir-butir soal tes. Mereka yang memperoleh skor rendah dikelompokan pada "siswa yang memiliki gaya kognitif spasial rendah" (GKSR) sedangkan mereka yang memperoleh skor tinggi dikelompokan pada "siswa yang memiliki gaya kognitif spasial tinggi" (GKST). Penentuan kelompok siswa yang memiliki gaya spasial tinggi dan rendah setelah skor diurutkan dari tinggi ke rendah adalah sebagai berikut : (1) $27 \%$ dari siswa yang memperoleh skor tinggi, dan (2) $27 \%$ siswa yang memiliki skor terendah adalah siswa yang memiliki gaya kognitif spasial rendah

\section{Desain Penelitian}

Penelitian dilakukan dengan menggunkan metode eksperimental. Variabel terikat hasil belajar ikatan kimia, khususnya topik tentang Bentuk Molekul Senyawa berdasarkan teori Hibridisasi. Rancangan yang dipakai adalah 2 × 2 faktorial. ${ }^{1}$ Variabel bebas perlakuan terdiri atas bentuk pebelajaran dengan menerapkan strategi pembelajaran model CDT Merrill dan strategi pembelajaran model PK Taba. Variabel bebas kedua adalah gaya kognitif spasial, terdiri atas gaya kognitif spasial tinggi dan gaya kognitif spasial rendah.

Pemilihan dua lokasi sekolah sebagai tempat pelaksanan penelitian dimaksudkan utuk menghindari adanya faktor confunding effects yaitu efek pembauran (Austin, 2011). Apabila kedua kelas perlakuan berada pada sekolah yang sama cenderung dapat menimbulkan efek pembaruan yang cukup dominan. Siswa-siswa pada kelas perlakuan berinteraksi sedemikian sehingga dapat menganggu kontrol terhadap perlakuan yang diberikan.

Pengumpulan data berbentuk tes adalah objektif pilihan ganda dengan lima alternatif jawaban.

Dalam pengembangan instrumen pengukuran hasil belajar Ikatan Kimia, langkahlangkah yang dilakukan adalah : (a) merumuskan definisi konseptual, (b) merumuskan definisi operasional, (c) membuat kisi-kisi instrumen (tes), dan (d) kalibrasi dan uji coba

Tabel 1. Matriks Rincian Jumlah Item Berdasarkan Tipe Unjuk Kerja dan Tipe Isi Ajaran

\begin{tabular}{lccc}
\hline $\begin{array}{l}\text { Tipe } \\
\text { unjuk } \\
\text { kerja } \\
\begin{array}{l}\text { Tipe isi } \\
\text { ajaran }\end{array}\end{array}$ & Mengingat & Menggunakan & Jumlah \\
\hline Fakta & $\begin{array}{c}4,18,19, \\
32,33,\end{array}$ & - & 5 \\
\hline Konsep & $\begin{array}{c}5,6,20, \\
34\end{array}$ & $\begin{array}{c}7,16,7,21, \\
30,31,35\end{array}$ & 11 \\
\hline Prosedur & $\begin{array}{c}3,1,22,17 \\
36\end{array}$ & $\begin{array}{c}9,11,23,25, \\
37,39\end{array}$ & 11 \\
\hline Kaidah & $\begin{array}{c}10,12,24, \\
26,38,40\end{array}$ & $\begin{array}{c}2,13,14,15, \\
27,28,29\end{array}$ & 13 \\
\hline Jumlah & 19 & 21 & 40 \\
\hline
\end{tabular}




\section{HASIL DAN PEMBAHASAN}

Deskripsi data yang diperoleh di dalam penelitian adalah sebagai berikut:

Tabel 2. Data Hasil Penelitian

\begin{tabular}{|c|c|c|c|c|}
\hline \multicolumn{2}{|c|}{$\begin{array}{l}\text { Sumber } \\
\text { statistik }\end{array}$} & $\begin{array}{r}\mathrm{A}_{1} \\
\text { (CDT } \\
\text { Merrill) }\end{array}$ & $\begin{array}{r}\mathrm{A}_{2} \\
(\mathrm{PK} \\
\text { Taba) }\end{array}$ & $\sum \mathrm{b}$ \\
\hline $\mathrm{B}_{1}$ & $\underline{\mathrm{n}}$ & 13 & 13 & 26 \\
\hline \multirow{2}{*}{ (Tinggi) } & $\bar{X}$ & 73,15 & 74,00 & 73,57 \\
\hline & $\mathrm{s}$ & 4,33 & 4,62 & 4,50 \\
\hline \multirow{3}{*}{$\begin{array}{l}\mathrm{B}_{2} \\
\text { (Rendah) }\end{array}$} & $\underline{\mathrm{n}}$ & 13 & 13 & 26 \\
\hline & & 69,30 & 61,77 & 65,53 \\
\hline & $\mathrm{s}$ & 6,84 & 5,48 & 7,05 \\
\hline \multirow{3}{*}{$\sum \mathrm{k}$} & $\mathrm{n}$ & 26 & 26 & 52 \\
\hline & X & 70,30 & 68,20 & 69,59 \\
\hline & $\mathrm{s}$ & 6,09 & 8,32 & 7,12 \\
\hline
\end{tabular}

Keterangan :

$\mathrm{A}_{1} \quad=$ kelompok siswa yang diajar dengan strategi pembelajaran berdasarkan model CDT Merrill

$\mathrm{A}_{2} \quad=$ kelompok siswa yang diajar dengan strategi pembelajaran berdasarkan model Pembentukan Konsep (PK Taba)

$\mathrm{B}_{1} \quad=$ kelompok siswa yang memiliki gaya kognitif spasial tinggi

$\mathrm{B}_{2}=$ kelompok siswa yang memiliki gaya kognitif spasial rendah

$\mathrm{n}=$ banyak sampel pada setiap kelompok

$X=$ skor rata-rata hasil belajar ikatan kimia

$\mathrm{s} \quad=$ simpangan baku

1. Hasil belajar Ikatan Kimia siswa yang diajar dengan strategi pembelajaran berdasarkan model CDT Merrill $\left(\mathbf{A}_{1}\right)$

Dalam kelompok ini, jumlah siswa sebanyak 26 orang. Skor yang diperoleh siswa memiliki rentang $(\mathrm{R})=22($ tersebar dari skor 58 hingga 80$)$. Harga rata-rata $(X)=70,977$ dengan simpangan baku 6,278.

Distribusi skor hasil belajar Ikatan Kimia siswa yang diajar dengan strategi pembelajaran model CDT Merrill disajikan melalui tabel di bawah ini

Tabel 3. Hasil Belajar Ikatan Kimia Siswa Yang Diajar Dengan Starategi Pembelajaran Model CDT Merrill

\begin{tabular}{lllll}
\hline $\begin{array}{l}\text { Kela } \\
\mathrm{s}\end{array}$ & $\begin{array}{l}\text { Interv } \\
\text { al } \\
\text { Kelas }\end{array}$ & $\begin{array}{l}\text { Nilai } \\
\text { Tenga } \\
\mathrm{h} \\
(\mathrm{Xi})\end{array}$ & $\begin{array}{l}\text { Frekuen } \\
\text { si } \\
\text { Absolut } \\
\left(\mathrm{F}_{\text {abs }}\right)\end{array}$ & $\begin{array}{l}\text { Frekuen } \\
\text { si Relatif } \\
\left(\mathrm{F}_{\text {ref }}\right)\end{array}$ \\
\hline 1 & 58 & $-59,5$ & 3 & 11,54 \\
2 & 61 & 63,5 & 2 & 7,69 \\
3 & 62 & $-67,5$ & 5 & 19,23 \\
4 & 65 & 71,5 & 8 & 30,77 \\
5 & & 75,5 & 3 & 11,54 \\
\hline
\end{tabular}

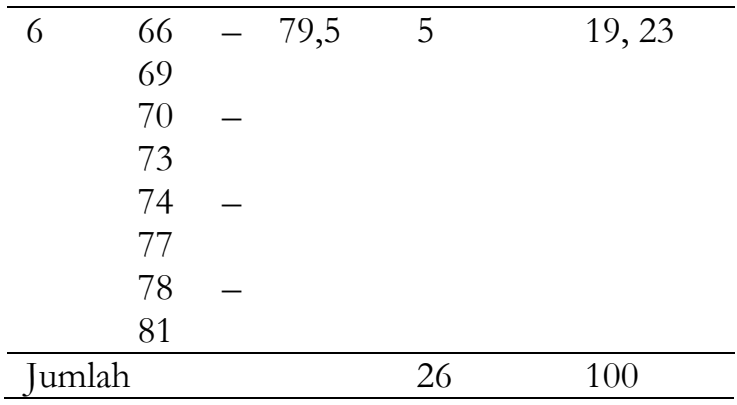

2. Hasil belajar Ikatan Kimia siswa yang diajar dengan strategi pembelajaran berdasarkan model Pembentukan Konsep (PK) Taba ( $\left.\mathrm{A}_{2}\right)$

Dalam kelompok ini, jumlah siswa sebanyak 26 orang. Skor yang diperoleh siswa memiliki rentang $(\mathrm{R})=29$ (tersebar dari 55 dan 84). Harga rerata $(X)$ $=68,20$ dengan simpangan baku $=7,70$.

Distribusi skor hasil belajar Ikatan Kimia siswa yang diajar dengan strategi pembelajaran berdasarkan model Pembentukan (PK) Taba disajikan dalam tabel 4:

Tabel 4. Hasil Belajar Ikatan Kimia Siswa Yang Diajar Dengan Strategi Pembelajaran Berdasarkan Model PK Taba

\begin{tabular}{lllll}
\hline Kelas & $\begin{array}{l}\text { Interval } \\
\text { Kelas }\end{array}$ & $\begin{array}{l}\text { Nilai } \\
\text { Tengah } \\
(\mathrm{Xi})\end{array}$ & $\begin{array}{l}\text { Frekuensi } \\
\text { Absolut } \\
\left(\mathrm{F}_{\text {abs }}\right)\end{array}$ & $\begin{array}{l}\text { Frekuensi } \\
\text { Relatif } \\
\left(\mathrm{F}_{\text {ref }}\right)\end{array}$ \\
\hline 1 & $55-59$ & 57 & 6 & 23,07 \\
2 & $60-64$ & 62 & 2 & 7,69 \\
3 & $65-69$ & 67 & 5 & 19,23 \\
4 & $70-74$ & 72 & 7 & 26,93 \\
5 & $75-79$ & 77 & 4 & 15,39 \\
6 & $80-84$ & 82 & 2 & 7,69 \\
\hline Jumlah & & & 26 & 100 \\
\hline
\end{tabular}

3. Hasil belajar Ikatan Kimia dari siswa yang memiliki gaya kognitif spasial tinggi yang diajar dengan strategi pembelajaran berdasarkan Model CDT Merrill $\left(\mathrm{A}_{1} \mathrm{~B}_{1}\right)$

Dalam kelompok ini, jumlah siswa sebanyak 13 orang $(\mathrm{n}=13)$. Skor yang diperoleh siswa memiliki rentang $(\mathrm{R})=15$ (tersebar dari 66 hingga 81). Harga rata-rata $(X)=73,15$ dengan simpangan baku $=4,50$.

Distribusi skor hasil belajar Ikatan Kimia dari siswa yang memiliki gaya kognitif spasial tinggi dan diajar dengan strategi pembelajaran Model CDT Merrill disajikan dalam tabel 5: 
Tabel 5. Hasil Belajar Ikatan Kimia Siswa Yang Memiliki Gaya Kognitif Spasial Tinggi Yang Diajar Dengan Strategi Pembelajaran Model CDT Merrill

\begin{tabular}{lllll}
\hline Kelas & $\begin{array}{l}\text { Interval } \\
\text { Kelas }\end{array}$ & $\begin{array}{l}\text { Nilai } \\
\text { Tengah } \\
(\mathrm{Xi})\end{array}$ & $\begin{array}{l}\text { Frekuensi } \\
\text { Absolut } \\
\left(\mathrm{F}_{\text {abs }}\right)\end{array}$ & $\begin{array}{l}\text { Frekuensi } \\
\text { Relatif } \\
\left(\mathrm{F}_{\text {ref }}\right)\end{array}$ \\
\hline 1 & $65-67$ & 66 & 1 & $7,70 \%$ \\
2 & $68-70$ & 69 & 3 & $23,07 \%$ \\
3 & $71-73$ & 72 & 4 & $30,76 \%$ \\
4 & $74-76$ & 75 & 1 & $7,70 \%$ \\
5 & $77-79$ & 78 & 3 & $23,07 \%$ \\
6 & $80-82$ & 81 & 1 & $7,70 \%$ \\
\hline Jumlah & & & 13 & 100 \\
\hline
\end{tabular}

4. Hasil belajar Ikatan Kimia dari siswa yang memiliki gaya kognitif spasial rendah yang diajar dengan strategi pembelajaran berdasarkan model CDT Merrill $\left(\mathrm{A}_{1} \mathrm{~B}_{2}\right)$

Dalam kelompok ini, jumlah siswa sebanyak 13 orang $(\mathrm{n}=13)$. Skor yang diperoleh siswa memiliki rentang $(\mathrm{R})=19$ tersebar dari skor 58 hingga 77. Harga rerata $(X)=69,3$ dengan simpangan baku $=6,67$

Distribusi skor hasil belajar Ikatan Kimia dari siswa yang memiliki gaya kognitif spasial rendah dan diajar dengan dtrategi pembelajaran berdasarkan model CDT Merrill disajikan dalam tabel di bawah ini:

Tabel 6. Hasil Belajar Ikatan Kimia Dari Siswa Yang Memiliki Gaya Kognitif Spasial Rendah Yang diajar Dengan Strategi Pembelajaran Berdasarkan Model CDT Merrill

\begin{tabular}{lllll}
\hline $\begin{array}{l}\text { Kela } \\
\mathrm{s}\end{array}$ & $\begin{array}{l}\text { Interva } \\
1\end{array}$ & $\begin{array}{l}\text { Nilai } \\
\text { Tenga } \\
\mathrm{h} \\
(\mathrm{Xi})\end{array}$ & $\begin{array}{l}\text { Frekuens } \\
\text { i Absolut } \\
\left(\mathrm{F}_{\text {abs }}\right)\end{array}$ & $\begin{array}{l}\text { Frekuens } \\
\mathrm{i} \text { Relatif } \\
\left(\mathrm{F}_{\text {ref }}\right)\end{array}$ \\
\hline 1 & $58-61$ & 59,5 & 2 & $15,39 \%$ \\
2 & $62-65$ & 63,5 & 2 & $15,39 \%$ \\
3 & $66-69$ & 67,5 & 2 & $15,39 \%$ \\
4 & $70-73$ & 71,5 & 3 & $23,07 \%$ \\
5 & $74-77$ & 74,5 & 4 & $30,76 \%$ \\
\hline Jumlah & & 13 & 100 \\
\hline
\end{tabular}

5. Hasil belajar ikatan kimia dari siswa yang memiliki gaya kognitif spasial tinggi dan diajar dengan strategi pembelajaran berdasarkan model PK Taba $\left(\mathrm{A}_{2} \mathrm{~B}_{1}\right)$

Dalam kelompok ini, jumlah siswa sebanyak 13 orang $(n=13)$. Skor yang diperoleh siswa memiliki rentang $(\mathrm{R})=17$ (tersebar dari 65 hingga 82). Dengan rerata $(X)=74,00$ dengan simpangan baku $=4,81$.
Distribusi skor hasil belajar ikatan kimia siswa yang memiliki daya kognitif spasial tinggi dan diajar dengan strategi pembelajaran model PK Taba disajikan dalam tabel berikut ini:

Tabel 7. Hasil Belajar Ikatan Kimia Siswa Yang Memiliki Gaya Kognitif Spasial Tinggi Yang Diajar Berdasarkan Model PK Taba

\begin{tabular}{lllll}
\hline $\begin{array}{l}\text { Kela } \\
\mathrm{s}\end{array}$ & $\begin{array}{l}\text { Interval } \\
\text { Kelas }\end{array}$ & $\begin{array}{l}\text { Nilai } \\
\text { Tengah } \\
(\mathrm{Xi})\end{array}$ & $\begin{array}{l}\text { Frekue } \\
\text { nsi } \\
\text { Absolu } \\
\mathrm{t}\left(\mathrm{F}_{\text {abs }}\right)\end{array}$ & $\begin{array}{l}\text { Frekuens } \\
\mathrm{i} \text { Relatif } \\
\left(\mathrm{F}_{\text {ref }}\right)\end{array}$ \\
\hline 1 & $65-67$ & 66 & 2 & $15,38 \%$ \\
2 & $68-70$ & 69 & 1 & $7,70 \%$ \\
3 & $71-73$ & 72 & 4 & $30,77 \%$ \\
4 & $74-76$ & 75 & 1 & $7,70 \%$ \\
5 & $77-79$ & 78 & 3 & $23,07 \%$ \\
6 & $80-82$ & 81 & 2 & $15,38 \%$ \\
\hline Jumlah & & 13 & 100 \\
\hline
\end{tabular}

6. Hasil belajar ikatan kimia dari siswa yang memiliki gaya kognitif spasial rendah yang diajar dengan strategi pembelajaran berdasarkan model PK Taba $\left(\mathrm{A}_{2} \mathrm{~B}_{2}\right)$

Dalam kelompok ini, jumlah siswa sebanyak 13 orang $(\mathrm{n}=13)$. Skor yang diperoleh siswa memiliki rentang $(\mathrm{R})=17$ tersebar dar skor 55 hingga 72. Dengan nilai rerata $X=61,77$ dan simpangan baku $=5,70$.

Distribusi skor hasil belajar ikatan kimia dari siswa yang memiliki gaya kognitif spasial rendah dan diajar dengan strategi pembelajaran berdasarkan model PK Taba disajikan dalam tabel berikut ini

Tabel 8. Hasil Belajar Ikatan Kimia Siswa Yang Memiliki Gaya Kognitif Spasial Rendah Yang Diajar Dengan Strategi Pembelajaran Model PK Taba

\begin{tabular}{lllll}
\hline $\begin{array}{l}\text { Kela } \\
\mathrm{s}\end{array}$ & $\begin{array}{l}\text { Interva } \\
1\end{array}$ & $\begin{array}{l}\text { Nilai } \\
\text { Tenga } \\
\mathrm{h} \\
(\mathrm{Xi})\end{array}$ & $\begin{array}{l}\text { Frekuens } \\
\mathrm{i} \text { Absolut } \\
\left(\mathrm{F}_{\text {abs }}\right)\end{array}$ & $\begin{array}{l}\text { Frekuens } \\
\mathrm{i} \text { Relatif } \\
\left(\mathrm{F}_{\text {ref }}\right)\end{array}$ \\
\hline 1 & $55-57$ & 56 & 4 & $30,77 \%$ \\
2 & $58-60$ & 59 & 3 & $23,07 \%$ \\
3 & $61-63$ & 62 & 1 & $7,70 \%$ \\
4 & $64-66$ & 65 & 2 & $15,38 \%$ \\
5 & $67-69$ & 68 & 1 & $7,70 \%$ \\
6 & $70-72$ & 71 & 2 & $15,38 \%$ \\
\hline Jumlah & & & 13 & 100 \\
\hline
\end{tabular}

\section{KESIMPULAN}

Berdasarkan data yang diperoleh, hasil pengujian hipotesis, dan pembahasan hasil penelitian ditemukan hal-hal sebagai berikut: (1) Hasil belajar Ikatan Kimia tentang Bentuk Molekul Senyawa Kovalen Netral berdasarkan Teori VSEPR, pada siswa yang diajar dengan strategi 
CDT Merrill lebih tinggi daripada hasil belajar siswa yang diajar dengan strategi Pembentukan Konsep PK Taba. (2) Siswa yang memiliki gaya kognitif spasial tinggi memberikan perolehan belajar Ikatan Kimia yang lebih tinggi dibandingkan dengan siswa yang memiliki gaya kognitif spasial rendah; (3) Ada pengaruh interaksi antara strategi pembelajaran dan gaya kognitif spasial terhadap pencapaian hasil belajar Ikatan Kimia.

Kesimpulan secara umum dapat dinyatakan bahwa untuk meningkatkan hasil belajar Ikatan Kimia siswa khususnya Topik VSEPR dapat dilakukan dengan menggunakan strategi pembelajaran berdasarkan model CDT Merri

\section{DAFTAR PUSTAKA}

Dharmaperwira-Prins, Reni.I.I. 2014. Gangguangangguan Komunikasi Pada Disfungsi hemisfer kanan dan pemeriksaan komunikasi pada hemisfer kanan. Terjemahan Yita dharma. Jakarta: Percetakan Ikrar Mandiri Abadi

Gunawan, A.W. 2014. Genius Learning Strategi : Petunjuk Praktis untuk Menerapkan Accelerated Learning. Jakarta: PT. Gramedia Pustaka Utama

Depdiknas. 2014. Pedoman Khusus Pengembangan Silabus dan Penilaian Mata Pelajaran Kimia. Jakarta: Dirjen Dikdasmen

Effendy. 2006. Teori VSEPR, Tinjauan Bentuk Molekul dan Bentuk Ion Poliatomik Berdasarkan Energitika dan Implikasinya pada Pengajaran Kimia di SMU. Malang: Jurusan Kimia FPMIPA IKIP Malang

Haryono. 2002. Efektivitas Pendekatan Keterampilan Proses dan Ekspositori dalam Pembelajaran Sains Ditinjau dari Cara Berpikir Siswa. Jakarta: Jurnal Teknologi Pendidikan Universitas Negeri Jakarta

Herhacki, M. 2015. Quantum Learning : Membiasakan Belajar Nyaman dan Menyenangkan. Terjemahan Alwiah Abdulrahman. Bandung: Penerbit Kaifa PT.Mizan Pustaka

Hidayanto, D. N. 2015. Pengembangan Pembelajaran "Berbasis Component Display Theory (CDT)". Jakarta: PT. Bumi Pustaka
Lourdusamy. 2005. Perbedaan Gaya Kognitif Individu dan Implikasinya Terhadap Pendidikan. Malaysia: Universiti Sains Malaysia.

Lucas, B. 2006. Optimalkan Otak Anda terjemahan Vitri Mayastuti. Jakarta: PT Bhuana Ilmu Populer

Lwin, K. \& Sim, C. 2005. Cara Mengembangkan Berbagai Komponen Kecerdasan (How to Multiply Your Child's Inteligience), terjemahan Christine Sujana. Jakarta: PT Indeks Kelompok Gramedia

Macneil, R. D. 1980. The Relationship of Cognitive Style and Instructional Style to the Learning Performance of Undergraduate Studens. Journal of Educational Research, Volume: 73, Issue:6, p.34 (http://www.questia.com/PM.qst?a $=$ o\&d= 77505441)

Miarso, Yi. 2004. Menyemai Benih Tehnologi Pendidikan. Jakarta: Pustekom Diknas Permen Nomor 19. 2005. Standar Nasional Pendidikan. Jakarta: Departemen Pendidikan Nasional

Retno, D.S. 2008. Strategi Pembelajaran Kimia. Medan: Program Pascasarjana Unimed

Purba, M. 2013. Kimia untuk SMA Kelas X. Jakarta: Erlangga

Sanjaya, W. 2008. Strategi Pembelajaran Berorientasi Standar Proses Pendidikan. Jakarta: Kencana Prenada Media Group

Sagala, S. 2003. Konsep dan Makna Pembelajaran. Bandung: Alfabeta

Semiawan, C. R., Th.I. 2007. Panorama Filsafat Ilmu: Landasan Perkembangan Ilmu Sepanjang Zaman. Jakarta: PT.Gramedia

Sunardi. 2008. Kimia Bilinggual untuk SMA Kelas XI. Jakarta: Yrama Widya

Surapranata, S. 2005. Analisis Validitas Reliabilitas dan Interpretasi Hasil Tes. Bandung: PT Remaja Rosdakarya. 